\title{
Changes in ruminal bacterial community composition following feeding of alfalfa ensiled with a lactic acid bacterial inoculant ${ }^{1}$
}

\author{
R. Mohammed, ${ }^{*}$ D. M. Stevenson, ${ }^{*}$ K. A. Beauchemin, $†$ R. E. Muck, ${ }^{* 2}$ and P. J. Weimer \\ *USDA-ARS, US Dairy Forage Research Center, Madison, WI 53706 \\ †AAFC, Lethbridge Research Center, Lethbridge, AB, Canada T1J 4B1
}

\begin{abstract}
Some silage inoculants help to improve silage quality and promote an increase in milk production, possibly through altering the rumen microflora. We hypothesized that rumen bacterial community composition (BCC) would be different in cows fed alfalfa ensiled with the inoculant Lactobacillus plantarum MTD/1 (LP) compared with those fed alfalfa ensiled without the inoculant (Ctrl). Eight ruminally cannulated Holstein cows were allotted to 2 diets (Ctrl or LP) in a double crossover design with four 28-d periods. Diets were formulated to contain (\% dry matter basis) $28.0 \%$ neutral detergent fiber and $16.2 \%$ crude protein, and contained alfalfa silage, 50.9 ; corn silage, 20.6; highmoisture shelled corn, 21.4; soy hulls, 4.7; plus minerals and vitamins, 2.4. Ruminal digesta were collected just before feeding on 3 consecutive days near the end of each period, and were separated into solid and liquid phases. Microbial DNA was extracted from each phase, amplified by PCR using domain-level bacterial primers, and subjected to automated ribosomal intergenic spacer analysis. The $\mathrm{pH}$ was 4.56 and 4.86 and the lactate-to-acetate ratio 9.8 and 4.4, respectively, for the treated and untreated alfalfa silages. Dry matter intakes and milk production data were not influenced by diets but showed a cow effect. Total volatile fatty acids $(\mathrm{m} M)$ tended to be greater for LP compared with Ctrl. Individual volatile fatty acids were not influenced by diets but showed a significant cow effect. Ruminal acetate $(\mathrm{mol} / 100 \mathrm{~mol})$ and acetate-to-propionate ratio were lower and propionate $(\mathrm{mol} / 100 \mathrm{~mol})$ greater for the 2 milk fat-depressed (MFD; $<3.2 \%$ fat content) cows compared with the other 6 cows. Correspondence analysis of the 265 peaks in the automated ribosomal intergenic spacer analysis profile across the 188 samples revealed that the first 2 components contributed 7.1
\end{abstract}

\footnotetext{
Received April 27, 2011.

Accepted September 14, 2011.

${ }^{1}$ Mention of specific products is provided for informational purposes only and does not represent an endorsement or warranty of these products by the USDA over other products not mentioned.

${ }^{2}$ Corresponding author: Richard.Muck@ars.usda.gov
}

and $3.8 \%$ to the total variation in the profile. The ordination points representing the liquid and solid phases clustered separately, indicating that these phases differed in BCC. The analysis of similarity data showed differences between Ctrl and LP. The lactic acid bacterial counts $\left(\log _{10} \mathrm{cfu} / \mathrm{g}\right.$ of wet silage) were 3.94 and 4.53 for the untreated and treated silage, respectively, at ensiling. The relative population size (RPS) of $L$. plantarum, determined by real-time PCR of $16 \mathrm{~S}$ rRNA gene copies, was greater in LP compared with Ctrl. The ordination points corresponding to certain individual cows clustered separately, and the most distinctive bacterial communities were those associated with MFD cows. The RPS of Megasphaera elsdenii was greater in 1 of the 2 MFD cows, although mean RPS of M. elsdenii did not differ between the treatments. In addition to the differences in rumen BCC between LP and Ctrl, MFD cows also displayed differences in BCC compared with cows with normal milk fat yield.

Key words: rumen, silage inoculant, microbial populations, milk fat depression

\section{INTRODUCTION}

Lactic acid bacterial (LAB) inoculants are used as additives in ensiling to enhance the preservation efficiency of silage and to improve animal performance. Desirable features of a silage inoculant include the ability to (1) rapidly lower the silage $\mathrm{pH},(2)$ lower ethanol and ammonia nitrogen content, and (3) increase the lactate-to-acetate ratio and DM recovery (Weinberg and Muck, 1996). Silage additives containing LAB are commonly used in commercial inoculants to achieve the desired properties described above. However, it should be noted that LAB inoculants do not consistently yield the desirable silage properties if the crop is low in fermentable sugars due to excessive wilting, cloudy weather, or rain (Kung, 2009).

Several studies have reported the beneficial effects of LAB inoculants on silage fermentation (reviewed by Weinberg and Muck, 1996). In addition, some LAB inoculants have also been reported to improve animal performance by increasing milk yield and feed 
efficiency (Kung and Muck, 1997; Kung et al., 2003). An average increase in milk yield of $1.4 \mathrm{~kg} / \mathrm{cow}$ per day was reported in $47 \%$ of the studies when inoculated silage was offered (Kung and Muck, 1997), with a more consistent increase in milk yield when silage was inoculated with the strain Lactobacillus plantarum MTD/1 (Kung et al., 2003). Some studies using silage inoculated with $L$. plantarum reported better animal performance even when the inoculant did not appear to improve the quality of the fermentation (Gordon, 1989; Steen et al., 1989), leading to the speculation that LAB inoculants may possibly act as probiotics. A probiotic is a viable culture of microorganisms that favors the growth of useful bacteria and inhibits the growth of pathogenic bacteria. Weinberg et al. (2003, 2004) demonstrated that silage inoculant LAB survived in rumen fluid in vitro. Recently, Contreras-Govea et al. (2011) reported that rumen microbial biomass yield determined in vitro was greater for the forage ensiled with the silage inoculants L. plantarum, Lactobacillus pentosus, and Lactococcus lactis than for those ensiled with L. plantarum + Enterococcus faecium and the uninoculated control. The ability of the LAB inoculants favoring increased microbial biomass led to the speculation that LAB inoculants could possibly affect rumen bacterial community composition (BCC) and population sizes of other bacteria in the rumen. However, the effect of specific strains of LAB on rumen BCC has not been explored.

We hypothesized that rumen BCC would be different in cows fed alfalfa ensiled with the inoculant Lactobacillus plantarum MTD/1 (LP) compared with those fed alfalfa ensiled without the inoculant $(\mathbf{C t r l})$. The objectives were to (1) examine rumen BCC of dairy cows as affected by feeding LP using the community fingerprinting technique, automated ribosomal intergenic spacer analysis (ARISA), and (2) determine the relative population size (RPS) of the inoculant $(L$. plantarum MTD/1).

\section{MATERIALS AND METHODS}

\section{Experimental Design}

Experiments were conducted in accordance with a research protocol approved by the University of Wisconsin-Madison's Research Animal Resource Center. Eight ruminally cannulated Holstein cows (111 DIM, $46 \mathrm{~kg} / \mathrm{d}$ average milk yield) were blocked by DIM and average milk yield forming 2 groups (4 cows each). Each group was randomly assigned to 2 experimental diets in a double crossover design with four 28-d periods. Diets were Ctrl and LP (Lactobacillus plantarum MTD/1 inoculant; Ecosyl Products Ltd., Yorkshire,
UK). The inoculant was applied to fourth-cut alfalfa at $1.0 \times 10^{5} \mathrm{cfu} / \mathrm{g}$ of the crop (in liquid form) at the forage harvester. Alfalfa was wilted in the field to approximately $50 \%$ DM. The inoculated treatment was harvested first from alternate windrows chopped to a theoretical chop length of $10 \mathrm{~mm}$ and ensiled in an oxygen-limiting tower silo. Later the same day the untreated alfalfa was harvested with the same equipment and ensiled in another oxygen-limiting tower silo. Total LAB counts were determined in alfalfa (treated and untreated) at ensiling, following the procedure described by Contreras-Govea et al. (2011). Duplicate samples of alfalfa silage (treated and untreated), corn silage and high-moisture corn were freeze-dried, ground through a 1-mm screen and analyzed for CP (Leco FP2000A nitrogen analyzer; Leco Corp., St. Joseph, MI). Neutral detergent fiber (with heat-stable amylase) and ADF content were determined using the procedure of Robertson and Van Soest (1977) as modified by Hintz et al. (1996) to include sodium sulfite during refluxing. About $20 \mathrm{~g}$ of silage samples were diluted 10:1 with autoclaved distilled water, blended in a 0.5 -L blender for $30 \mathrm{~s}$ and filtered through 4 layers of cheesecloth. The filtrate was immediately used for $\mathrm{pH}$ determination. An aliquot $(20 \mathrm{~mL})$ of the filtrate was centrifuged in a $50 \mathrm{~mL}$ polypropylene tube at $25,000 \times g$ for $25 \mathrm{~min}$ and the supernatant was stored at $-20^{\circ} \mathrm{C}$ before analyzing the fermentation products using HPLC (Muck and Dickerson, 1988). The fermentation characteristics and chemical composition of alfalfa silage (treated and untreated), corn silage, and high-moisture corn is tabulated (Table 1). Diets were formulated to contain (\% DM basis) $28.0 \%$ amylase-treated NDF, and $16.2 \%$ CP. Total mixed rations containing (\% DM) were as follows: alfalfa silage, 50.9; corn silage, 20.6; high-moisture shelled corn, 21.4; soy hulls, 4.7; plus supplemental minerals and vitamins, 2.4 (Vita-Plus Corp., Madison, WI) were fed ad libitum once daily.

Milk samples were collected (a.m. and p.m.) on $4 \mathrm{~d}$ (d $20,21,27$, and 28) in each period for the determination of fat, protein, lactose, and MUN contents using near infrared spectroscopy (AgSource Cooperative Services, Verona, WI). Rumen digesta were collected just before feeding on 3 consecutive days of each period (d 22-24) by manual mixing before sampling and spot sampled from midpoint along the length of the rumen (rumen mat) and from the midpoint along the height of the rumen contents (ventral rumen). It should be noted that rumen digesta confined to the rumen epithelium was not sampled. After collection, rumen digesta were squeezed through 4 layers of cheesecloth to separate the solid (SO) and liquid (L) phases. Volatile fatty acids were determined from the $\mathrm{L}$ phase of rumen digesta by HPLC (Weimer et al., 1991). Microbial DNA was 
Table 1. Fermentation and nutritive characteristics of untreated alfalfa, treated alfalfa, corn silage, and highmoisture corn

\begin{tabular}{lccrc}
\hline Item & $\begin{array}{c}\text { Untreated alfalfa } \\
\text { silage }(\mathrm{n}=16)\end{array}$ & $\begin{array}{c}\text { Treated }^{1} \text { alfalfa } \\
\text { silage }(\mathrm{n}=17)\end{array}$ & $\begin{array}{c}\text { Corn silage } \\
(\mathrm{n}=17)\end{array}$ & $\begin{array}{c}\text { High-moisture } \\
\text { corn }(\mathrm{n}=17)\end{array}$ \\
\hline $\mathrm{DM}(\%)$ & $49.3 \pm 1.65$ & $48.3 \pm 1.11$ & $31.4 \pm 0.26$ & $73.3 \pm 0.17$ \\
$\mathrm{pH}$ & $4.86 \pm 0.06$ & $4.56 \pm 0.02$ & $3.82 \pm 0.01$ & $4.60 \pm 0.02$ \\
Lactate (g/kg of DM) & $63.1 \pm 5.79$ & $75.8 \pm 2.09$ & $59.4 \pm 2.55$ & $11.7 \pm 0.39$ \\
Acetate (g/kg of DM) & $15.3 \pm 1.88$ & $8.3 \pm 0.70$ & $33.6 \pm 2.28$ & $2.6 \pm 0.52$ \\
Lactate:acetate & $4.4 \pm 0.19$ & $9.8 \pm 0.54$ & $2.0 \pm 0.26$ & $5.5 \pm 0.38$ \\
Ethanol (g/kg of DM) & $1.0 \pm 0.12$ & $0.7 \pm 0.09$ & $6.0 \pm 0.54$ & $2.0 \pm 0.22$ \\
CP (\% DM) & $25.1 \pm 0.23$ & $25.1 \pm 0.09$ & $6.9 \pm 0.07$ & $7.3 \pm 0.07$ \\
NDF (\% DM) & $31.7 \pm 0.28$ & $31.5 \pm 0.24$ & $37.2 \pm 0.87$ & $4.0 \pm 0.16$ \\
ADF (\% DM) & $24.1 \pm 0.25$ & $23.8 \pm 0.38$ & $21.1 \pm 0.59$ & $1.1 \pm 0.05$ \\
Ash (\% DM) & $10.4 \pm 0.21$ & $9.9 \pm 0.17$ & $3.8 \pm 0.14$ & $1.2 \pm 0.03$ \\
\hline
\end{tabular}

${ }^{1}$ Silage inoculant containing Lactobacillus plantarum (Ecosyl MTD/1) was applied to fourth-cut alfalfa silage at $1.0 \times 10^{5} \mathrm{cfu} / \mathrm{g}$ of crop.

extracted from the L phase directly, but the SO phase was first homogenized in a blender with chilled extraction buffer $(100 \mathrm{~m} M$ Tris-HCl, $10 \mathrm{~m} M$ EDTA, $0.15 M$ $\mathrm{NaCl} \mathrm{pH} \mathrm{8.0)} \mathrm{to} \mathrm{release} \mathrm{the} \mathrm{solids-associated} \mathrm{bacteria}$ as described by Stevenson and Weimer (2007). In brief, DNA was extracted from $25 \mathrm{~mL}$ of $\mathrm{L}$ phase and $25 \mathrm{~g}$ of SO phase of rumen digesta using a series of wash steps with the extraction buffer, followed by lysis of the microbial cells in a bead beater, extraction with combinations of phenol/chloroform, and precipitation with isopropanol (Stevenson and Weimer, 2007). The DNA obtained was resuspended in TE buffer $(10 \mathrm{mM}$ Tris-HCl, $1 \mathrm{~m} M$ EDTA, $\mathrm{pH}$ 8.0) and its concentration measured by spectrophotometry.

The internally transcribed region (ITS) between the bacterial $16 \mathrm{~S}$ and $23 \mathrm{~S}$ rRNA genes was amplified using domain-specific bacterial primers ITSF (5'-GTCGTAACAAGGTAGCCGTA-3') and ITSReub (5'-GCCAAGGCATCCAAC-3'). The primer ends were complementary to the respective positions 1423 and 1443 of the 23S rRNA and positions 38 and 23 of the 16S rRNA of Escherichia coli (Cardinale et al., 2004). The PCR components and the cycling conditions have been described previously (Weimer et al., 2010b). The PCR product obtained was resolved in a Beckman Coulter CEQ8000 Genetic Analysis System (Beckman Coulter Inc., Fullerton, CA) using the run parameters as described by Weimer et al. (2010b). In brief, $0.5 \mu \mathrm{L}$ of the PCR product was mixed with $1 \mu \mathrm{L}$ of Beckman Coulter WelRed \#1 infrared fluorescent dye-labeled DNA standard ladder (MapMarker 1000; Bio Ventures, Murfreesboro, TN) and $39 \mu \mathrm{L}$ of sample loading solution (Beckman Coulter Inc.) and loaded into microtiter plates. Capillary electrophoresis was conducted following the manufacturer's instructions after covering the liquid surface of the wells with molecular biology-grade mineral oil.
The raw data obtained from capillary electrophoresis were imported into GeneMarker software (v. 1.75; Soft Genetics LLC, State College, PA) for further analysis. Peak detection and quantification were performed using the settings for amplicon fragment-length polymorphism analysis described in the GeneMarker manual. Peak sizes (bp) were determined using the DNA standard ladder described above. Baseline subtraction and peak smoothing was performed as described in the GeneMarker manual. The panel generated by the software was screened manually to remove any questionable peaks caused by pull-up from the dyed DNA standard. All peaks corresponding to amplicon length $(\mathbf{A L})>112$ bp were exported for correspondence analysis (described under the statistical analysis section).

Quantitative real-time PCR (qRT-PCR) assay was conducted with the $\mathrm{L}$ phase of rumen digesta. The primers used for targeting the recA gene of L. plantarum (LacPla1F 5'-AGG CGC GGC TGA TGT CA-3' and LacPla1R 5'-CGC GAT TGT CTT GGT TTT GTT-3') were previously validated for their specificity (Stevenson et al., 2006). These primers are complementary to the respective positions 503 to 570 of the recA gene of Escherichia coli. The size of the resulting amplicon was $68 \mathrm{bp}$. It was preferred to target the recA gene instead of the $16 \mathrm{~S}$ rRNA gene because we have observed almost complete homology in the $16 \mathrm{~S}$ rRNA genes of several Lactobacillus species found in plant material (Stevenson et al., 2006). The standards for the L. plantarum assay were prepared by making a serial dilution of the genomic DNA obtained from a pure culture of the target strain. The standards and the set of samples belonging to each period were run in the same plate in triplicate. The RPS of L. plantarum was determined as the ratio of the amplification of target species (L. plantarum recA copy numbers) to the amplification of the background obtained by amplifying the 
16S rRNA gene with eubacterial primers (BAC338F and BAC805R, Yu et al., 2005). The qRT-PCR was conducted using POWER SYBR Green PCR Master Mix (Applied Biosystems, Warrington, UK), forward and reverse primers (25 pmol of each primer/reaction) and approximately $20 \mathrm{ng}$ of template DNA in a final volume of $25 \mu \mathrm{L}$ per reaction. Quantitative real-time PCR assays were conducted using the Applied Biosystems Prism 7300 sequence detection system. The cycling conditions for amplifying the recA gene of $L$. plantarum included 40 cycles of $95^{\circ} \mathrm{C}$ for $15 \mathrm{~s}$ and $59^{\circ} \mathrm{C}$ for $60 \mathrm{~s}$ and for the eubacterial $16 \mathrm{~S}$ rRNA gene, 40 cycles of $95^{\circ} \mathrm{C}$ for $15 \mathrm{~s}, 50^{\circ} \mathrm{C}$ for $60 \mathrm{~s}$, and $72^{\circ} \mathrm{C}$ for $90 \mathrm{~s}$ were used. The efficiency of the PCR was calculated as the negative reciprocal of the slope of the line obtained by plotting cycle threshold (Ct) versus log DNA concentrations of the standard dilution series.

The design and validation of primers for Megasphaera elsdenii (MegEls2F 5'-AGA TGG GGA CAA CAG CTG GA-3' and MegEls2R 5'-CGA AAG CTC CGA AGA GCC T-3') has been reported earlier (Stevenson and Weimer, 2007). Relative population size of M. elsdenii was determined as the ratio of $16 \mathrm{~S}$ rRNA gene copies amplified with the specific primers to the $16 \mathrm{~S}$ rRNA gene copies amplified with the eubacterial primers. The amplification conditions for $M$. elsdenii were 40 cycles of $95^{\circ} \mathrm{C}$ for $15 \mathrm{~s}$ and $59^{\circ} \mathrm{C}$ for $60 \mathrm{~s}$. Readers should note that the determination of RPS of a rumen bacterium using the ratio of $16 \mathrm{~S}$ rRNA gene copies is a relative quantification approach, and may sometimes over- or underestimate the absolute differences in the numbers of the bacterium under investigation.

\section{Statistical Analysis}

The data matrix resulting from the export of peak areas from GeneMarker were analyzed by correspondence analysis following the method of Ludwig and Reynolds (1988) using custom software written in the C programming language. Two ordination points (out of 192 total) corresponding to the $\mathrm{L}$ phase in 2 cows in the first period were identified as outliers. These 2 samples together with the corresponding samples in the SO phase were excluded from the analysis. The ordination points for the first 2 components were plotted as scatter plots. The ordination points for fitting vectors for the variables milk fat yield and VFA were calculated using the method of vector fitting described by McCune and Grace (2002).

The relative peak areas obtained from ARISA were analyzed for the shifts in BCC using analysis of similarity (ANOSIM; Clarke, 1993). Four data matrices were constructed from the ARISA data (L and SO phase for LP and Ctrl treatments) corresponding to each cow.
Each data matrix contained 265 rows (corresponding to the different AL) and 12 columns (3 daily samples for each of the 4 periods). The ANOSIM statistic, conventionally termed the R-value, was determined using Bray-Curtis dissimilarity rankings (Clarke, 1993). A higher R-value indicates greater differences in the BCC and the probability values represent the fraction of these $\mathrm{R}$-values that exceeded the $\mathrm{R}$-value obtained from the randomized comparison.

Dry matter intakes, production data, rumen VFA data and the RPS of L. plantarum and M. elsdenii averaged per cow per period $(\mathrm{n}=32)$ were analyzed using the MIXED procedure of SAS. Cow within diet was the experimental unit with group, cow, treatment, and period designated as fixed effects in the model. Because group and period were not significant $(P>0.05)$ for all the variables (except for RPS of $L$. plantarum), they were removed subsequently from the model.

\section{RESULTS}

\section{Fermentation and Nutritive Characteristics of Silages}

Prior to ensiling, alfalfa contained $50 \%$ DM, and (DM basis) $24 \% \mathrm{CP}, 30 \% \mathrm{NDF}, 22 \% \mathrm{ADF}$, and $5.6 \%$ acid detergent lignin. The nutritive value of alfalfa silage remained closer to that of the original crop with a negligible loss in DM (Table 1). The fermentation characteristics of treated alfalfa silage were better than those of untreated alfalfa silage based on the lower $\mathrm{pH}$ and greater lactate content and lactate-to-acetate ratio of the former relative to the latter. Butyrate was not detected and propionate was negligible in alfalfa silage (data not shown).

\section{Intakes and Production}

Dry matter intakes, milk yield, and milk components (content and yield), and MUN were not influenced by diet but a cow effect was observed without any interaction between cow and treatment (Table 2). Milk fat concentration was lower for cows 3016 and 3436 compared with the other cows, whereas milk fat yield $(\mathrm{kg} / \mathrm{d})$ was lower for cows 3436 and 3295 than for the other cows.

\section{Rumen VFA}

Total VFA $(\mathrm{m} M)$ tended to be greater $(P=0.08)$ for LP than for Ctrl (Table 3). However, individual VFA proportions were not influenced by diets. A significant cow effect was observed for all of the individual VFA. Ruminal acetate (molar proportion) was lower and propionate greater for the milk fat-depressed (MFD; 
Table 2. Dry matter intake and production data in dairy cows offered alfalfa silage inoculated (LP), or not (Ctrl), with a lactic acid bacterial inoculant ${ }^{1}$

\begin{tabular}{|c|c|c|c|c|c|c|c|c|c|c|c|c|c|c|c|}
\hline \multirow[b]{2}{*}{ Variable } & \multicolumn{2}{|c|}{ Treatment } & \multirow[b]{2}{*}{ SEM } & \multirow[b]{2}{*}{$P$-value } & \multicolumn{8}{|c|}{ Cow } & \multirow[b]{2}{*}{ SEM } & \multirow[b]{2}{*}{$P$-value } & \multirow{2}{*}{$\begin{array}{c}\text { Cow } \times \\
\text { treatment }\end{array}$} \\
\hline & Ctrl & LP & & & 2623 & 2674 & 3016 & 3035 & 3039 & 3085 & 3295 & 3436 & & & \\
\hline DMI $(\mathrm{kg} / \mathrm{d})$ & 24.8 & 25.5 & 0.39 & 0.27 & $29.0^{\mathrm{a}}$ & $27.2^{\mathrm{ab}}$ & $23.2^{\mathrm{c}}$ & $28.5^{\mathrm{a}}$ & $24.2^{\mathrm{bc}}$ & $26.2^{\mathrm{ab}}$ & $22.9^{c}$ & $20.2^{\mathrm{d}}$ & 0.79 & $<0.01$ & 0.21 \\
\hline Milk yield $(\mathrm{kg} / \mathrm{d})$ & 36.9 & 37.7 & 1.17 & 0.68 & $39.8^{\mathrm{a}}$ & $42.6^{\mathrm{a}}$ & $41.9^{\mathrm{a}}$ & $45.5^{\mathrm{a}}$ & $33.6^{\mathrm{b}}$ & $31.7^{\mathrm{b}}$ & $27.8^{\mathrm{b}}$ & $35.5^{\mathrm{ab}}$ & 2.34 & $<0.01$ & 0.58 \\
\hline Milk yield $/ \mathrm{kg}$ of DMI & 1.49 & 1.48 & 0.03 & 0.88 & $1.37^{\mathrm{bc}}$ & $1.56^{\mathrm{bc}}$ & $1.79^{\mathrm{a}}$ & $1.60^{\mathrm{b}}$ & $1.38^{\mathrm{bc}}$ & $1.21^{\mathrm{b}}$ & $1.21^{\mathrm{c}}$ & $1.76^{\mathrm{a}}$ & 0.06 & $<0.01$ & 0.87 \\
\hline Milk fat (\%) & 3.71 & 3.84 & 0.07 & 0.19 & $4.09^{\mathrm{ab}}$ & $3.72^{\mathrm{bc}}$ & $3.08^{\mathrm{d}}$ & $3.61^{\mathrm{bc}}$ & $4.55^{\mathrm{a}}$ & $4.51^{\mathrm{a}}$ & $3.81^{\mathrm{b}}$ & $2.84^{\mathrm{d}}$ & 0.14 & $<0.01$ & 0.76 \\
\hline Fat yield $(\mathrm{kg} / \mathrm{d})$ & 1.37 & 1.43 & 0.04 & 0.31 & $1.67^{\mathrm{a}}$ & $1.60^{\mathrm{a}}$ & $1.29^{\mathrm{b}}$ & $1.61^{\mathrm{a}}$ & $1.52^{\mathrm{ab}}$ & $1.44^{\mathrm{ab}}$ & $1.07^{\mathrm{c}}$ & $1.01^{\mathrm{c}}$ & 0.08 & $<0.01$ & 0.39 \\
\hline Protein $(\%)$ & 2.82 & 2.81 & 0.02 & 0.63 & $2.98^{\mathrm{b}}$ & $2.79^{\mathrm{c}}$ & $2.51^{\mathrm{d}}$ & $2.33^{\mathrm{e}}$ & $3.07^{\mathrm{b}}$ & $3.13^{\mathrm{ab}}$ & $3.25^{\mathrm{a}}$ & $2.47^{\mathrm{d}}$ & 0.04 & $<0.01$ & 0.26 \\
\hline Protein $(\mathrm{kg} / \mathrm{d})$ & 1.04 & 1.04 & 0.03 & 0.88 & $1.22^{\mathrm{a}}$ & $1.21^{\mathrm{a}}$ & $1.05^{\mathrm{ab}}$ & $1.05^{\mathrm{ab}}$ & $1.03^{\mathrm{b}}$ & $0.98^{\mathrm{b}}$ & $0.90^{\mathrm{b}}$ & $0.88^{\mathrm{b}}$ & 0.06 & $<0.01$ & 0.78 \\
\hline Lactose $(\%)$ & 4.85 & 4.90 & 0.04 & 0.32 & $4.68^{\mathrm{c}}$ & $4.77^{\mathrm{c}}$ & $4.99^{\mathrm{ab}}$ & $4.70^{\mathrm{c}}$ & $5.17^{\mathrm{a}}$ & $4.85^{\mathrm{c}}$ & $4.95^{\mathrm{b}}$ & $4.89^{\mathrm{bc}}$ & 0.08 & $<0.01$ & 0.29 \\
\hline Lactose $(\mathrm{kg} / \mathrm{d})$ & 1.82 & 1.83 & 0.07 & 0.84 & $1.91^{\mathrm{ab}}$ & $2.07^{\mathrm{a}}$ & $2.10^{\mathrm{a}}$ & $2.12^{\mathrm{a}}$ & $1.74^{\mathrm{b}}$ & $1.53^{\mathrm{bc}}$ & $1.39^{\mathrm{bc}}$ & $1.75^{\mathrm{ab}}$ & 0.14 & 0.01 & 0.56 \\
\hline MUN (mg/dL) & 12.5 & 12.1 & 0.43 & 0.54 & $12.6^{\mathrm{ab}}$ & $11.4^{\mathrm{bc}}$ & $14.3^{\mathrm{a}}$ & $13.6^{\mathrm{ab}}$ & $11.5^{\mathrm{b}}$ & $13.6^{\mathrm{ab}}$ & $9.4^{\mathrm{c}}$ & $12.2^{\mathrm{ab}}$ & 0.86 & 0.02 & 0.55 \\
\hline
\end{tabular}

${ }^{\mathrm{a} e} \mathrm{Least}$ squares means within cows in a row with different superscripts differ $(P<0.05)$

${ }^{1}$ Silage inoculant containing Lactobacillus plantarum $\left(\right.$ Ecosyl MTD/1) was applied to fourth-cut alfalfa at $1.0 \times 10^{5} \mathrm{cfu} / \mathrm{g}$ of crop.

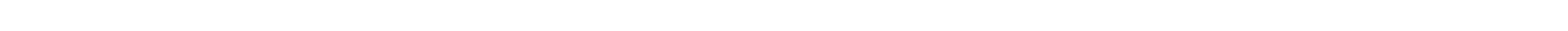

Table 3. Rumen fermentation and milk fat variables in dairy cows offered alfalfa silage inoculated (LP), or not (Ctrl), with a lactic acid bacterial inoculant ${ }^{1}$

\begin{tabular}{|c|c|c|c|c|c|c|c|c|c|c|c|c|c|c|c|}
\hline \multirow[b]{2}{*}{ Variable } & \multicolumn{2}{|c|}{ Treatment } & \multirow[b]{2}{*}{ SEM } & \multirow[b]{2}{*}{$P$-value } & \multicolumn{8}{|c|}{ Cow } & \multirow[b]{2}{*}{ SEM } & \multirow[b]{2}{*}{$P$-value } & \multirow{2}{*}{$\begin{array}{c}\text { Cow } x \\
\text { treatmen }\end{array}$} \\
\hline & Ctrl & LP & & & 2623 & 2674 & 3016 & 3035 & 3039 & 3085 & 3295 & 3436 & & & \\
\hline $\begin{array}{l}\text { Total VFA }(\mathrm{m} M) \\
\mathrm{mol} / 100 \mathrm{~mol}\end{array}$ & 120.4 & 129.6 & 3.45 & 0.08 & 109.2 & 139.3 & 123.1 & 118.3 & 120.9 & 139.2 & 123.2 & 126.8 & 6.91 & 0.09 & 0.31 \\
\hline Acetate $(\mathrm{Ac})$ & 68.3 & 68.5 & 0.36 & 0.72 & $70.7^{\mathrm{a}}$ & $69.9^{\mathrm{ab}}$ & $63.6^{\mathrm{c}}$ & $69.9^{\mathrm{ab}}$ & $71.2^{\mathrm{a}}$ & $68.2^{\mathrm{b}}$ & $70.8^{\mathrm{a}}$ & $63.1^{\mathrm{c}}$ & 0.72 & $<0.01$ & 0.55 \\
\hline Propionate (Pr) & 18.6 & 18.7 & 0.33 & 0.82 & $17.5^{\mathrm{bc}}$ & $16.9^{\mathrm{bc}}$ & $23.2^{\mathrm{a}}$ & $18.0^{\mathrm{b}}$ & $16.4^{\mathrm{bc}}$ & $18.2^{\mathrm{b}}$ & $15.9^{\mathrm{c}}$ & $23.1^{\mathrm{a}}$ & 0.66 & $<0.01$ & 0.63 \\
\hline Butyrate $(\mathrm{Bu})$ & 9.10 & 9.03 & 0.09 & 0.62 & $8.17^{\mathrm{c}}$ & $9.06^{\mathrm{b}}$ & $9.43^{\mathrm{ab}}$ & $8.62^{\mathrm{bc}}$ & $8.90^{\mathrm{b}}$ & $9.70^{\mathrm{a}}$ & $9.15^{\mathrm{ab}}$ & $9.46^{\mathrm{ab}}$ & 0.19 & $<0.01$ & 0.46 \\
\hline Isobutyrate & 0.84 & 0.79 & 0.02 & 0.29 & $0.92^{\mathrm{a}}$ & $0.89^{\mathrm{a}}$ & $0.64^{\mathrm{c}}$ & $0.73^{\mathrm{bc}}$ & $0.85^{\mathrm{ab}}$ & $0.81^{\text {ab }}$ & $0.93^{\mathrm{a}}$ & $0.73^{\mathrm{bc}}$ & 0.06 & 0.02 & 0.39 \\
\hline Valerate & 1.66 & 1.52 & 0.06 & 0.15 & $1.16^{\mathrm{b}}$ & $1.56^{\mathrm{b}}$ & $1.84^{\mathrm{ab}}$ & $1.44^{\mathrm{b}}$ & $1.40^{\mathrm{bc}}$ & $1.49^{\mathrm{b}}$ & $1.67^{\mathrm{b}}$ & $2.17^{\mathrm{a}}$ & 0.13 & $<0.01$ & 0.41 \\
\hline Isovalerate & 1.47 & 1.43 & 0.05 & 0.49 & $1.56^{\mathrm{a}}$ & $1.64^{\mathrm{a}}$ & $1.22^{\mathrm{b}}$ & $1.29^{\mathrm{b}}$ & $1.27^{\mathrm{b}}$ & $1.62^{\mathrm{a}}$ & $1.57^{\mathrm{a}}$ & $1.43^{\mathrm{ab}}$ & 0.09 & 0.02 & 0.84 \\
\hline Ac-to-Pr ratio & 3.78 & 3.76 & 0.07 & 0.88 & $4.07^{\mathrm{ab}}$ & $4.11^{\mathrm{ab}}$ & $2.77^{\mathrm{c}}$ & $3.88^{\mathrm{b}}$ & $4.36^{\mathrm{a}}$ & $3.76^{\mathrm{b}}$ & $4.47^{\mathrm{a}}$ & $2.74^{\mathrm{c}}$ & 0.14 & $<0.01$ & 0.35 \\
\hline $\mathrm{Ac}+\mathrm{Bu}$-to-Pr ratio & 4.28 & 4.25 & 0.08 & 0.84 & $4.54^{\mathrm{b}}$ & $4.65^{\mathrm{ab}}$ & $3.18^{\mathrm{c}}$ & $4.36^{\mathrm{b}}$ & $4.91^{\mathrm{a}}$ & $4.29^{\mathrm{b}}$ & $5.04^{\mathrm{a}}$ & $3.15^{\mathrm{c}}$ & 0.16 & $<0.01$ & 0.41 \\
\hline
\end{tabular}

${ }^{\mathrm{a}-\mathrm{C}}$ Least squares means within cows in a row with different superscripts differ $(P<0.05)$.

${ }^{1}$ Silage inoculant containing Lactobacillus plantarum (Ecosyl MTD/1) was applied to fourth-cut alfalfa at $1.0 \times 10^{5} \mathrm{cfu} / \mathrm{g}$ of crop. 
$<3.2 \%$ fat content) cows (3436 and 3016) compared with the other cows. Consistent with this, the ratios acetate to propionate and acetate + butyrate to propionate were also lower for the MFD cows than for the other cows. A tendency $(P=0.09)$ existed for a cow effect for total VFA. Cow by treatment interactions for total and individual VFA were not significant.

\section{$B C C$}

Total AL detected by the analysis of raw data generated from capillary electrophoresis of PCR products was 265 (range $=61-798 \mathrm{bp})$. The mean number of AL detected in individual samples was 113, ranging from a minimum of 36 to a maximum of 143 . The maximum number of AL detected in both digesta types were similar (138 in L and 143 in SO). The minimum number of AL detected in the SO digesta were 62 compared with 36 in $\mathrm{L}$ digesta, indicating greater fluctuations in the latter. Correspondence analysis of the ARISA profile across the entire data set revealed that the first 2 components contributed 7.1 and $3.8 \%$, respectively, to the total variation in the profile; these percentages, while small, are not unexpected due to the high dimensionality of the data set (36 to 143 amplicons per sample).

The ordination points representing the $\mathrm{L}$ and $\mathrm{SO}$ phases clustered separately (Figure 1A). In Figure 1B, ordination points corresponding to individual cows were spread along the first component ( $\mathrm{x}$-axis) with the majority of the ordination points clustering on the left, whereas a small but distinct set of ordination points clustered toward the right. This distinctly separated group of ordination points represented the MFD cows (3016 and 3436). It should be noted that the vector for milk fat yield showed in the direction of the first component (x-axis) but away from the ordination points corresponding to the MFD cows, indicating that ARISA profiles in this study were helpful in identifying the MFD cows from the normal cows. Vectors for milk fat content and acetate-to-propionate ratio were also in the same direction as milk fat yield (not shown in the figure). The vector for VFA was also in the same direction as milk fat yield, but not very strong, indicating a lower contribution of VFA to the variation in BCC.

Figure 2 displays the ordination points corresponding to treatments (Ctrl and LP) in individual cows. The ordination points above and below the dotted line represent SO and L phases, respectively. A closer examination of this figure revealed that diets tended to cluster together in each phase for most of the cows $(3295,2623$, 3436, 3016, and 3085), indicating treatment differences. Consistent with this, the ANOSIM data (Table 4) also showed differences in the pairs of dietary treatments compared within cows (greater R-values indicate greater differences). However, the ANOSIM data also showed differences when cows were offered the same diet (Ctrl vs. Ctrl or LP vs. LP) but in a different period, indicating an effect of the period or possibly adaptation of the bacterial community over time.

\section{Epiphytic LAB Counts and Relative Population Size of L. plantarum and M. elsdenii}

The epiphytic LAB counts for the untreated and treated alfalfa $\left(\log _{10} \mathrm{cfu} / \mathrm{g}\right)$ at ensiling were 3.94 and 4.53, respectively. The RPS of L. plantarum (expressed as percent of $16 \mathrm{~S}$ rRNA gene copy number) was greater for LP compared with Ctrl without any significant cow effect (Table 5). The RPS of M. elsdenii showed a significant cow effect with greater values observed for 1 of the MFD cows (3436) compared with the normal cows. However, the RPS of M. elsdenii was not different between treatments.

\section{DISCUSSION}

Automated ribosomal intergenic spacer analysis has been used as a microbial fingerprinting technique for studying BCC (Weimer et al., 2010a,b; Welkie et al., 2010). It should be noted that ARISA is well suited to obtain a broader picture of the shifts in the BCC, although it does not provide specific taxonomic information about the individual AL (Fisher and Triplett, 1999). Automated ribosomal intergenic spacer analysis is more sensitive compared with the alternative fingerprinting techniques [e.g., Denaturing gradient gel electrophoresis (DGGE) and temperature gradient gel electrophoresis (TGGE)] considering the greater mean number of AL detected (113 in this study) compared with the number of detectable bands in other fingerprinting techniques.

\section{$B C C$}

The $\mathrm{BCC}$ reported here reflects the bacterial communities in the rumen contents only and does not include bacteria confined to the rumen epithelium. The separation between the $\mathrm{L}$ and $\mathrm{SO}$ phases, evident from the lack of overlap in the ordination points between the 2 phases (Figure 1A), was consistent with the findings of Welkie et al. (2010) and Weimer et al. (2010b). This indicates that the L- and SO-associated rumen bacterial communities are substantially different, consistent with their preference for nutrient utilization in the SO and L phases. Ordination points for individual cow/treatment combinations, from samples collected on the last $3 \mathrm{~d}$ of each period were very similar in position, indicating that the BCC had reached a substantial degree of 


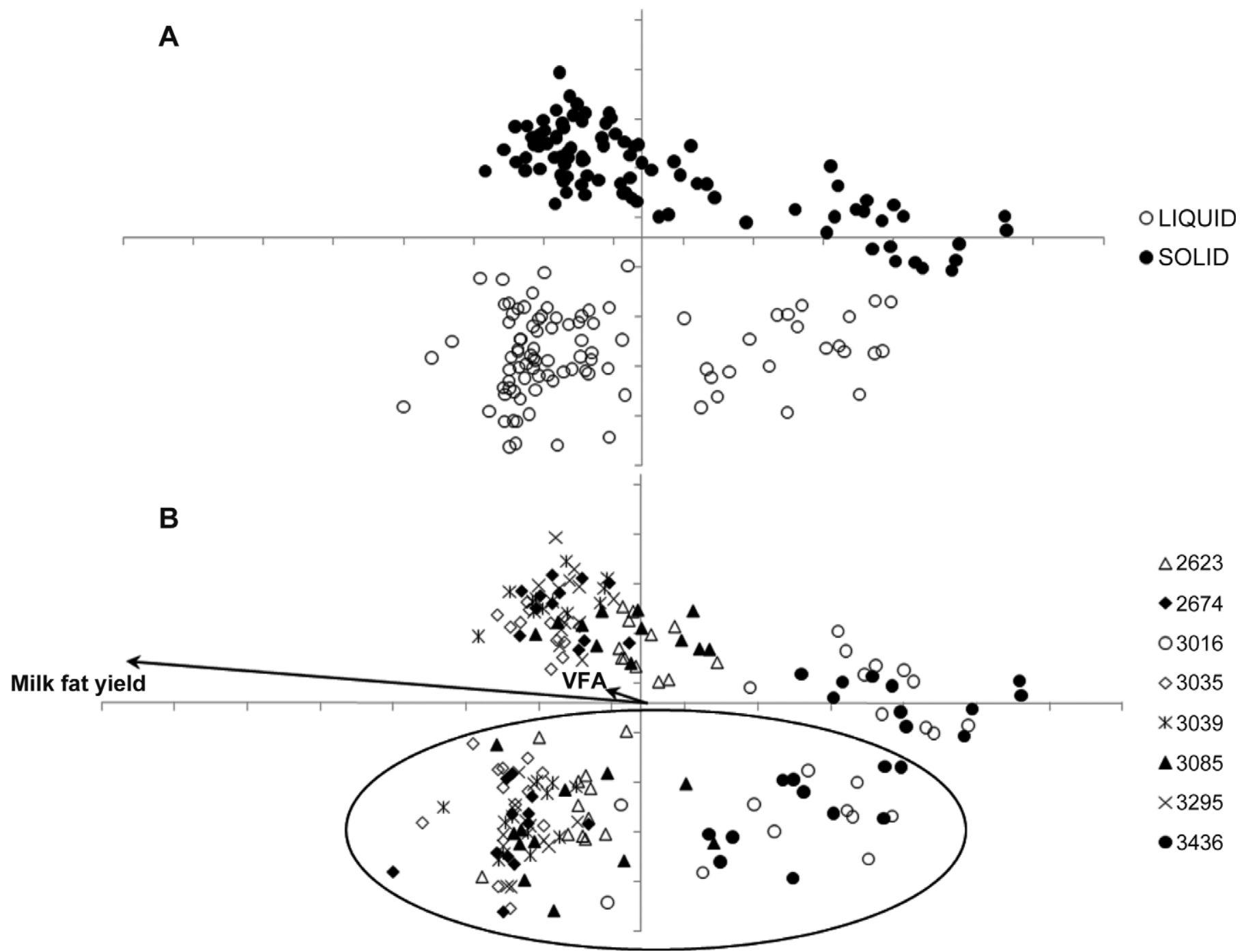

Figure 1. Scatter plot of the ordination points obtained from correspondence analysis of the automated ribosomal intergenic spacer analysis (ARISA) data matrix from 8 cows across 4 periods with 3 replicate samples per cow in a period obtained on 3 consecutive days (n = 188; 94 from each phase). Both Figures 1A and 1B were prepared with the same scale but are separated for clarity. In Figure 1A, the filled and open circles represent the ordination points corresponding to the solid and liquid phases of rumen digesta, respectively. In Figure 1B, the 8 different markers represent the ordination points corresponding to the 8 individual cows. The ordination points corresponding to the liquid phase are shown in the oval and the other points above the oval correspond to the solid phase. Note that the vector for milk fat yield is in a direction opposite to that of the ordination points, corresponding to the milk fat-depressed cows (3016 and 3436).

stability by the end of each 28 -d period. These results were in accord with previous studies in which a $28-\mathrm{d}$ period was sufficient to achieve stability following either substantial dietary changes (Weimer et al., 2010b) or severe perturbation resulting from almost complete exchange of ruminal contents (Weimer et al., 2010a). The ordination points corresponding to individual cows (Figure 1B) within each phase showed separation along the first component (which contributed greater variation), indicating that individual cows displayed shifts in the BCC. The clustering of the ordination points corresponding to each cow within a phase (evident in
Figure 2) is consistent with the findings that ruminal BCC displays substantial host specificity (Weimer et al., 2010a).

Several possible reasons exist for individual cows to be different in ruminal BCC even when offered the same diet. Some of the differences could be due to receipt of unique inocula from the dam (and possibly from other cows/calves) following birth, the nutritional history of the cow before the experiment, and the contribution of yet-undefined genetic factors that regulate the host-microbe symbiosis. Differences in BCC among individual cows on the same diet are also likely to occur due to 

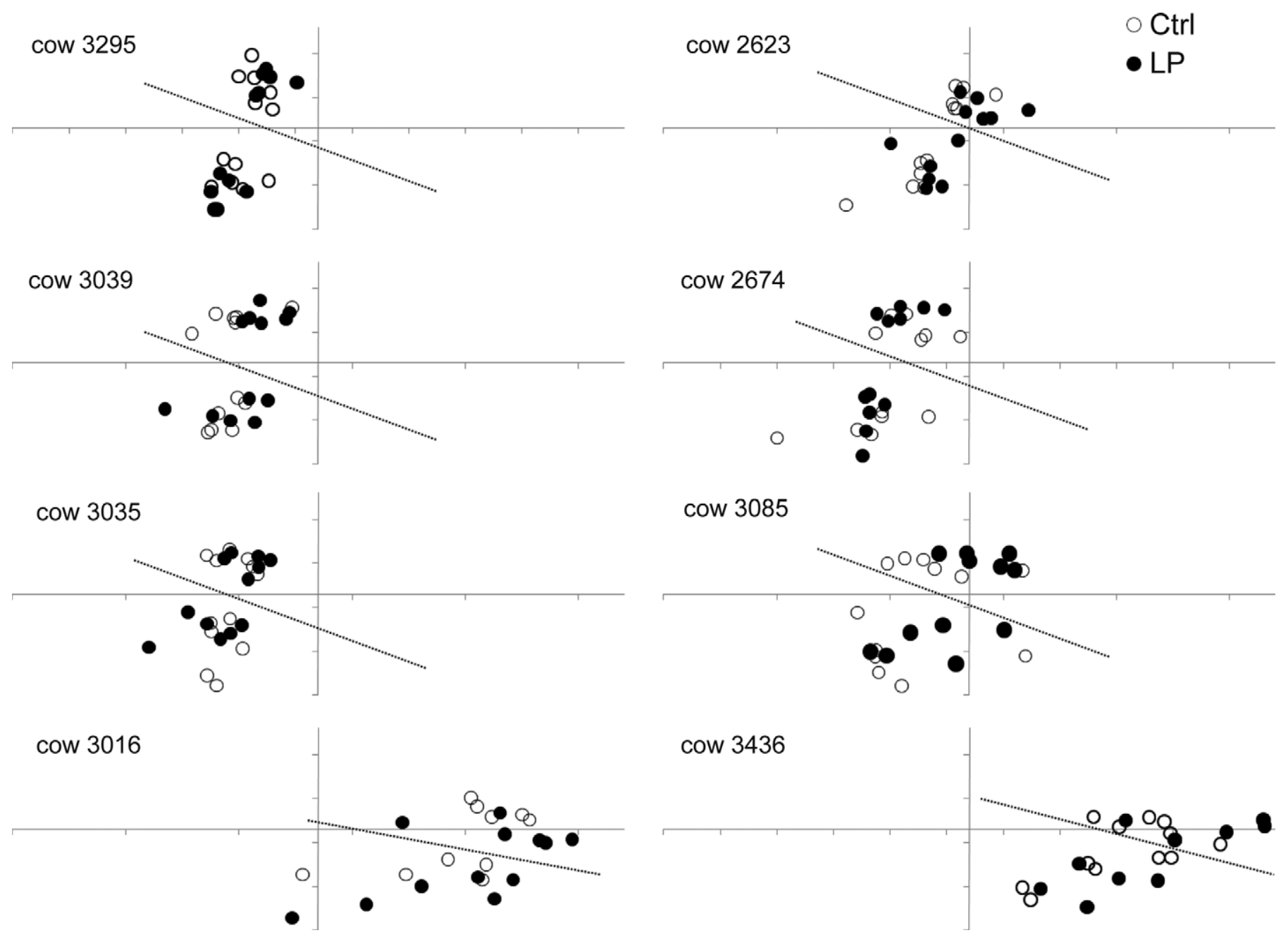

Figure 2. Scatter plot of the ordination points obtained from correspondence analysis of the automated ribosomal intergenic spacer analysis (ARISA) data matrix from 8 cows across 4 periods with 3 replicate samples per cow in a period obtained on 3 consecutive days. In this figure, individual cows are plotted separately for the purpose of clarity $(n=22$ for the cows 3016 and 3436 and $n=24$ for the other cows). The ordination points above and below the dotted lines represent solid and liquid phase of rumen digesta, respectively. All of the figures here have the same scale. The open and filled circles represent the control (Ctrl) and Lactobacillus plantarum MTD/1 inoculated silage (LP), respectively. Note the distinct scatter of the ordination points for the milk fat-depressed cows (3016 and 3436) compared with the other cows.

differences in rumen $\mathrm{pH}$ among cows (not measured). Low rumen $\mathrm{pH}$ decreases the efficiency of conversion of complex feed components into simpler end products that can affect the growth of rumen bacteria. However, differences in rumen $\mathrm{pH}$ alone do not explain differences in BCC (Palmonari et al., 2010). Thus, the differences among cows in their feeding behavior, salivary secretion, and nutrient absorption capacity of the epithelium are all likely to contribute to the variation in individual BCC among cows.

Although some overlap exists in the ordination points corresponding to individual cows, 2 cows (3016 and 3436 in Figure 1B and Figure 2) displayed profiles that differed from those of the other 6 . These 2 cows were identified as MFD cows (see Table 2). Previously,
Palmonari et al. (2010) and Weimer et al. (2010b) also reported that MFD cows displayed a distinct BCC demonstrating a strong association between MFD and shifts in BCC.

\section{Treatment and Cow Effects}

A 6-fold increase in total LAB counts at ensiling in the treated alfalfa compared with the untreated alfalfa could be attributed to the inoculant treatment. The increase in RPS of L. plantarum in LP compared with Ctrl was proportionately small but significant (Table 5). This discrepancy could be due to the use of species-specific (rather than group-specific) primers for quantifying $L$. plantarum in rumen fluid, in contrast 
Table 4. Analysis of similarity (ANOSIM) $)^{1}$ of bacterial community composition in liquid and solid phases of rumen digesta from dairy cows offered alfalfa silage inoculated with

(LP) and without (Ctrl) a commercial silage inoculant ${ }^{2}$

\begin{tabular}{|c|c|c|c|c|c|c|c|c|c|}
\hline \multirow[b]{2}{*}{ Treatment/period ${ }^{3}$} & \multicolumn{4}{|c|}{ Group $1 \mathrm{cow}^{4}$} & \multirow[b]{2}{*}{ Treatment/period ${ }^{3}$} & \multicolumn{4}{|c|}{ Group 2 cow $^{4}$} \\
\hline & 3295 & 2623 & 2674 & 3016 & & 3039 & 3035 & 3436 & 3085 \\
\hline Liquid phase & & & & & Liquid & & & & \\
\hline Ctrl-LP (period 1-2) & $0.704(0.009)$ & $0.259(0.009)$ & $0.111(0.029)$ & $1.000(0.009)$ & LP-Ctrl (period 1-2) & $0.444(0.009)$ & $0.333(0.009)$ & $1.000(0.009)$ & $0.704(0.009)$ \\
\hline Ctrl-LP (period 3-4) & $0.296(0.021)$ & $-0.037(0.958)$ & $0.074(0.030)$ & $0.000(0.311)$ & LP-Ctrl (period 3-4) & $0.220(0.021)$ & $0.481(0.009)$ & $0.037(0.039)$ & $0.333(0.009)$ \\
\hline Ctrl-Ctrl (period 1-3) & $0.778(0.009)$ & $0.296(0.009)$ & $0.148(0.009)$ & $0.500(0.009)$ & LP-LP (period 1-3) & $0.926(0.009)$ & $0.111(0.028)$ & $0.000(0.289)$ & $0.370(0.009)$ \\
\hline LP-LP (period 2-4) & $0.148(0.020)$ & $0.000(0.325)$ & $0.148(0.018)$ & $0.667(0.009)$ & Ctrl-Ctrl (period 2-4) & $0.000(0.326)$ & $1.000(0.009)$ & $1.000(0.009)$ & $0.185(0.031)$ \\
\hline Solid phase & & & & & Solid & & & & \\
\hline Ctrl-LP (period 1-2) & $0.185(0.021)$ & $0.778(0.009)$ & $0.333(0.02)$ & $-0.250(0.931)$ & LP-Ctrl (period 1-2) & $0.778(0.009)$ & $0.667(0.009)$ & $1.000(0.009)$ & $0.444(0.021)$ \\
\hline Ctrl-LP (period 3-4) & $0.259(0.028)$ & $0.407(0.021)$ & $0.296(0.018)$ & $0.926(0.009)$ & LP-Ctrl (period 3-4) & $0.667(0.009)$ & $0.222(0.009)$ & $0.667(0.009)$ & $0.518(0.020)$ \\
\hline Ctrl-Ctrl (period 1-3) & $0.259(0.019)$ & $0.704(0.009)$ & $0.741(0.009)$ & $0.500(0.009)$ & LP-LP (period 1-3) & $0.185(0.019)$ & $0.667(0.009)$ & $1.000(0.009)$ & $0.333(0.020)$ \\
\hline LP-LP (period 2-4) & $0.037(0.041)$ & $0.185(0.039)$ & $0.000(0.328)$ & $0.370(0.009)$ & Ctrl-Ctrl (period 2-4) & $0.407(0.009)$ & $0.296(0.021)$ & $0.037(0.048)$ & $0.555(0.021)$ \\
\hline
\end{tabular}

${ }^{1}$ The ANOSIM R-values were determined from Bray-Curtis dissimilarity measurements of the relative peak areas obtained from capillary electrophoresis. Higher ANOSIM R-values indicate greater differences in bacterial community composition between the 2 diets compared $(+1=$ maximally distinct; $-1=$ maximally similar $)$. Values in parentheses indicate probability of obtaining a larger ANOSIM value from randomized rankings of between-group similarities.

${ }^{2}$ Silage inoculant containing Lactobacillus plantarum (Ecosyl MTD/1) was applied to fourth-cut alfalfa at $1.0 \times 10^{5} \mathrm{cfu} / \mathrm{g}$ of $\mathrm{crop}$

${ }^{3} \mathrm{LP}=$ L. plantarum MTD/1-treated silage.

${ }^{4}$ The 8 cows in this study were blocked by DIM and average milk yield into 2 groups of 4 cows each. Cows in group 1 were allotted to Ctrl in periods 1 and 3 , respectively, and to LP in periods 2 and 4, respectively. Cows in group 2 were allotted to LP in periods 1 and 3, respectively, and to Ctrl in periods 2 and 4 , respectively.

Table 5. Percentages of target species in rumen liquid samples relative to total eubacterial content determined by quantitative real-time PCR (qRT-PCR) analysis ${ }^{1}$

\begin{tabular}{|c|c|c|c|c|c|c|c|c|c|c|c|c|c|c|c|}
\hline \multirow[b]{2}{*}{ Species $^{2}$} & \multicolumn{2}{|c|}{ Treatment } & \multirow[b]{2}{*}{ SEM } & \multirow[b]{2}{*}{$P$-value } & \multicolumn{8}{|c|}{ Cow } & \multirow[b]{2}{*}{ SEM } & \multirow[b]{2}{*}{$P$-value } & \multirow{2}{*}{$\begin{array}{l}\text { Cow } \times \\
\text { treatment }\end{array}$} \\
\hline & Ctrl & LP & & & 2623 & 2674 & 3016 & 3035 & 3039 & 3085 & 3295 & 3436 & & & \\
\hline $\begin{array}{l}\text { Lactobacillus plantarum } \\
\text { Megasphaera elsdenii }\end{array}$ & $\begin{array}{l}0.016 \\
0.040\end{array}$ & $\begin{array}{l}0.032 \\
0.060\end{array}$ & $\begin{array}{l}0.002 \\
0.019\end{array}$ & $\begin{array}{r}<0.01 \\
0.47\end{array}$ & $\begin{array}{l}0.024 \\
0.004^{\mathrm{b}}\end{array}$ & $\begin{array}{l}0.020 \\
0.003^{\mathrm{b}}\end{array}$ & $\begin{array}{l}0.032 \\
0.075^{\mathrm{b}}\end{array}$ & $\begin{array}{l}0.016 \\
0.004^{\mathrm{b}}\end{array}$ & $\begin{array}{l}0.023 \\
0.004^{\mathrm{b}}\end{array}$ & $\begin{array}{l}0.017 \\
0.003^{\mathrm{b}}\end{array}$ & $\begin{array}{l}0.033 \\
0.004^{\mathrm{b}}\end{array}$ & $\begin{array}{l}0.026 \\
0.298^{\mathrm{a}}\end{array}$ & $\begin{array}{l}0.013 \\
0.038\end{array}$ & $\begin{array}{r}0.97 \\
<0.01\end{array}$ & $\begin{array}{l}0.44 \\
0.93\end{array}$ \\
\hline
\end{tabular}

$\overline{\mathrm{a}, \mathrm{b}}$ Least squares means within cows in a row with different superscripts differ $(P<0.05)$.

${ }^{1}$ The 8 cows in this study were blocked by DIM and average milk yield into 2 groups of 4 cows each. Cows in group 1 were allotted to control (Ctrl) in periods 1 and 3 , respectively, and to L. plantarum MTD/1-treated silage (LP) in periods 2 and 4, respectively. Cows in group 2 were allotted to LP in periods 1 and 3 , respectively, and to Ctrl in periods 2 and 4 , respectively. Therefore, group and period within group were also included in the statistical model. A significant group $(P=0.04)$ and period within group $(P<0.01)$ effect was observed for L. plantarum.

${ }^{2}$ The relative population size (RPS) of L. plantarum was determined as the ratio of copies of the recA gene to copies of the $16 \mathrm{~S}$ rRNA gene amplified with eubacterial primers and expressed as percentage. The RPS of $M$. elsdenii was determined as the ratio of copies of the $16 \mathrm{~S}$ rRNA gene of the target species to copies of the $16 \mathrm{~S}$ rRNA gene amplified with eubacterial primers and expressed as percentage. 


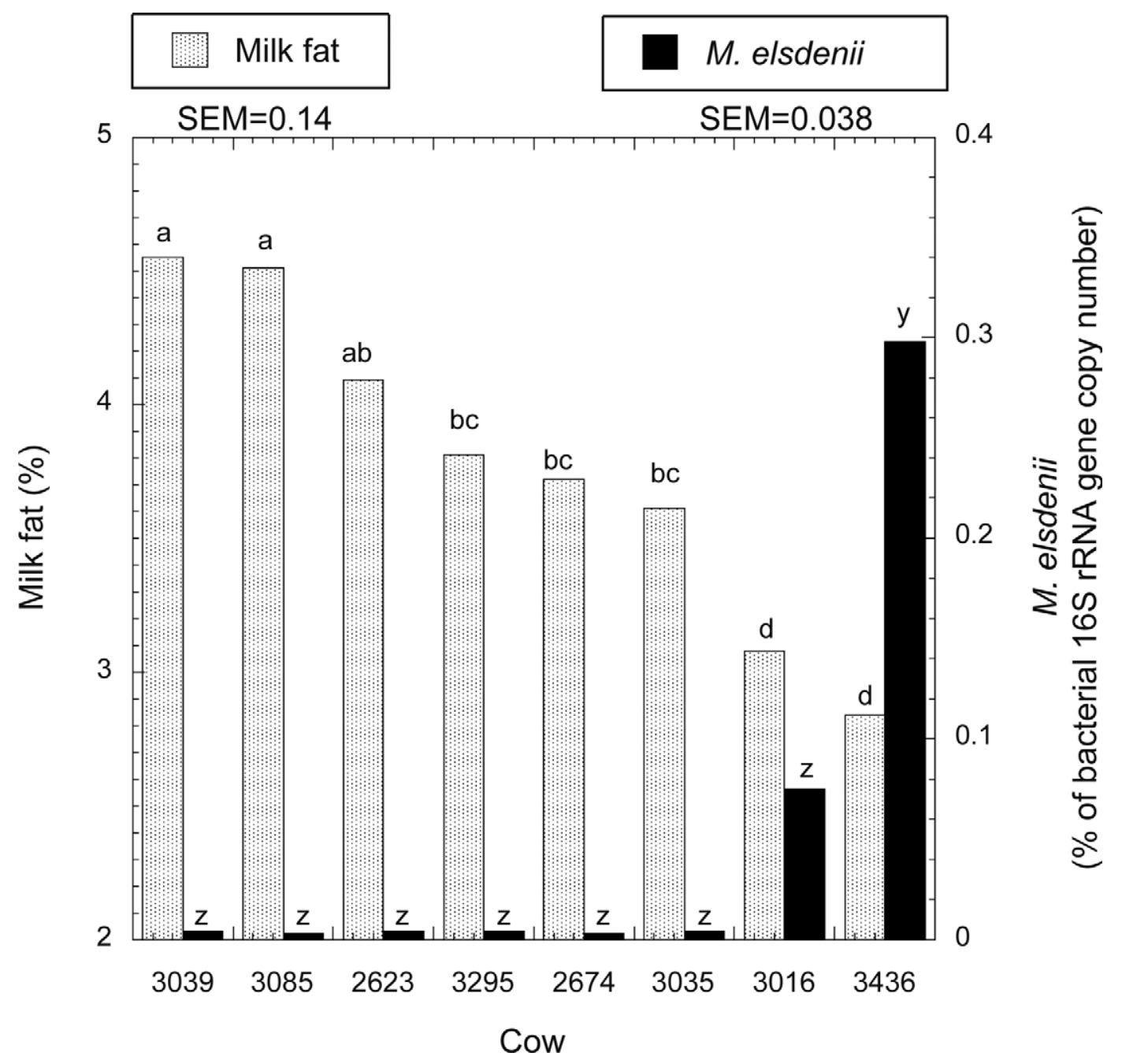

Figure 3. Individual cow differences in milk fat content (\%, left y-axis) and relative population size of Megasphaera elsdenii (\%, right y-axis). Note the inverse trend between the 2 variables. ${ }^{\mathrm{a}-\mathrm{d}}$ Least squares means for milk fat content with different letters differ $(P<0.05) ;{ }^{\mathrm{y}, \mathrm{z}}$ least squares means for relative population size of $M$. elsdenii with different letters differ $(P<0.05)$

to the LAB counts determined from the silage, which are based on plating onto selective media designed to cultivate a range of LAB genera.

An improvement in silage quality for the treated alfalfa compared with untreated alfalfa was evident from the lower $\mathrm{pH}$ and increase in lactate and lactate-toacetate ratio for the former than the latter. However, a lack of difference in DMI and milk yield between LP and Ctrl was not anticipated. Muck (1993) reported that the incidence of positive responses for intake and milk production was 25 and $40 \%$, respectively, in his review of inoculant studies from 1985 to 1992. Reviewing studies in which $L$. plantarum MTD/1 was used as an inoculant (Weinberg and Muck, 1996), it could be noticed that 6 of the 10 studies reported an improvement in both silage fermentation and animal performance; 2 studies reported only increased animal performance; whereas 1 study reported improvement in silage quality without any effect on animal performance. In the current study, cows were allotted to the diets in a double crossover design, resulting in all cows going through both diets twice. A lack of positive response in intakes and production could, therefore, be attributed to an increased variation in animal performance resulting from dietary changes across the 4 periods and possibly to the small number of animals used.

No treatment effects on milk fat content or yield were observed, but individual cow differences in milk fat yield resulted in a cow effect. Although we did not anticipate MFD in the current study due to the high forage content of diets, ARISA profiles showing distinct BCC for the 2 cows described above prompted us to explore this further. An increase in the RPS of M. elsdenii has been reported earlier in MFD cows (Palmonari et 
al., 2010; Weimer et al., 2010b). Consistent with their findings, the RPS of M. elsdenii in this study was also greater for 1 of the cows experiencing MFD (Table 5; Figure 3). It should be noted that cows experiencing MFD were also low in milk protein content and had greater efficiency of milk yield.

Although individual VFA were not influenced by treatments, a tendency for the increase in total VFA for LP compared with Ctrl demonstrates a positive effect of the inoculant. In a previous study, Contreras-Govea et al. (2011) reported a greater microbial biomass yield in the inoculated silage (third-cut alfalfa) compared with the control, despite the lack of difference in in vitro gas production and total VFA between treatments. It is worth exploring if a difference in microbial biomass yield could exist with or without a difference in total VFA.

The treatment effect is also evident in some of the cows showing clustering of the ordination points by diet (Figure 2). Furthermore, the greater ANOSIM R-values when cows moved from Ctrl to LP or vice versa also demonstrates a treatment effect. However, ANOSIM $\mathrm{R}$-values were also greater when cows offered the same diets in different periods were compared (Ctrl vs. Ctrl or LP vs. LP), indicating a period effect as well. A period effect can occur if a specific diet offered during a period is different in nutrient composition from the same diet offered in other periods. However, no differences existed in nutrient composition measured across periods (results not shown). We also used the same set of reagents for molecular analyses of samples to rule out possible effects on ARISA profiles. The feeding trial began in early April, and was completed in late July. It is possible that some of the period effect may be due to environmental effects on the cows (e.g., heat stress) that were not recorded.

\section{CONCLUSIONS}

This study evaluated the effect of alfalfa ensiled with or without the inoculant L. plantarum MTD/1 on silage quality, intakes, production, and rumen BCC in dairy cows. Inoculated alfalfa silage was better in quality compared with the untreated control based on the lower $\mathrm{pH}$ and greater lactate-to-acetate ratio for the former that the latter. No effect of the inoculant on animal performance occurred. Feeding silage prepared with the inoculant resulted in higher ruminal levels of L. plantarum and, in some cows, a detectable shift in bacterial community composition (BCC). However, differences in $\mathrm{BCC}$ between treatments were relatively minor compared with major differences in $\mathrm{BCC}$ between the $\mathrm{SO}$ and $\mathrm{L}$ phases of rumen digesta, and among cows that did, versus did not, display MFD. Milk fat de- pression was associated with an increase in the relative population size of the bacterium Megasphaera elsdenii. In addition to the differences in rumen $\mathrm{BCC}$ between LP and Ctrl, MFD cows also displayed differences in BCC compared with the cows with normal milk fat yield.

\section{ACKNOWLEDGMENTS}

This work was supported by the USDA Agricultural Research Service through CRIS project 3655-31000021-00D. We thank the US Dairy Forage Research Center (USDFRC; Madison, WI) barn crew for assistance with the animal trial and Christine Odt (USDFRC) for technical assistance.

\section{REFERENCES}

Cardinale, M., L. Brusetti, P. Quatrini, S. Borin, A. M. Puglia, A Rizzi, E. Zanardini, C. Sorlini, C. Corselli, and D. Daffonchio. 2004. Comparison of different primer sets for use in automated ribosomal intergenic spacer analysis of complex bacterial communities. Appl. Environ. Microbiol. 70:6147-6156.

Clarke, K. R. 1993. Non-parametric multivariate analyses of changes in community structure. Aust. J. Ecol. 18:117-143.

Contreras-Govea, F. E., R. E. Muck, D. R. Mertens, and P. J. Weimer. 2011. Microbial inoculants effects on silage and in vitro ruminal fermentation, and microbial biomass estimation for alfalfa, bmr corn, and corn silages. Anim. Feed Sci. Technol. 163:2-10.

Fisher, M. M., and E. W. Triplett. 1999. Automated approach for ribosomal intergenic spacer analysis of microbial diversity and its application to freshwater bacterial communities. Appl. Environ. Microbiol. 65:4630-4636.

Gordon, F. J. 1989. A further study of the evaluation through lactating cattle of a bacterial inoculant as an additive for grass silage. Grass Forage Sci. 44:353-357.

Hintz, R. W., D. R. Mertens, and K. A. Albrecht. 1996. Effects of sodium sulfite on recovery and composition of detergent fiber and lignin. J. AOAC Int. 79:16-22.

Kung, L., Jr. 2009. Potential factors that may limit the effectiveness of silage additives. Pages 37-45 in Proc. XV International Silage Conference, Madison, WI. G. A. Broderick, A. T. Adesogan, L. W. Bocher, K. K. Bolsen, F. E. Contreras-Govea, J. H. Harrison, and R. E. Muck, ed. US Dairy Forage Research Centre, Madison, WI.

Kung, L., Jr., and R. E. Muck. 1997. Animal response to silage additives. Pages 200-210 in Silage: Field to Feedbunk, NRAES-99. Northeast Regional Agric. Eng. Service, Ithaca, NY.

Kung, L., Jr., M. R. Stokes, and C. J. Lin. 2003. Silage additives. Pages 305-360 in Silage Science and Technology. Agron. Monogr. 42. D. R. Buxton, R. E. Muck, and J. H. Harrison, ed. Am. Soc. Agronomy (ASA), Crop Sci. Soc. of America (CSSA), and Soil Sci. Soc. of America (SSSA), Madison, WI.

Ludwig, J. A., and J. F. Reynolds. 1988. Statistical Ecology. John Wiley and Sons, New York, NY.

McCune, B., and J. B. Grace. 2002. Analysis of ecological communities. MjM Software Design, Gleneden Beach, Oregon.

Muck, R. E. 1993. The role of silage additives in making high quality silage. Pages 106-116 in Silage Production from Seed to Animal, NRAES-67. Northeast Regional Agric. Eng. Service, Syracuse, NY.

Muck, R. E., and J. T. Dickerson. 1988. Storage temperature effects on proteolysis in alfalfa silage. Trans. ASABE 31:1005-1009.

Palmonari, A., D. M. Stevenson, D. R. Mertens, C. W. Cruywagen, and P. J. Weimer. 2010. pH dynamics and bacterial community composition in the rumen of lactating dairy cows. J. Dairy Sci. 93:279-287.

Robertson, J. B., and P. J. Van Soest. 1977. Dietary fiber estimation in concentrate feedstuffs. J. Anim. Sci. 45(Suppl. 1):254-255. (Abstr.) 
Steen, R. W. J., E. F. Unsworth, H. I. Gracey, S. J. Kennedy, R. Anderson, and D. J. Kilpatrick. 1989. Evaluation studies in the development of a commercial bacterial inoculant as an additive for grass silage. 3. Response in growing cattle and interaction with protein supplementation. Grass Forage Sci. 44:381-390.

Stevenson, D. M., R. E. Muck, K. J. Shinners, and P. J. Weimer. 2006. Use of real time PCR to determine population profiles of individual species of lactic acid bacteria in alfalfa silage and stored corn stover. Appl. Microbiol. Biotechnol. 71:329-338.

Stevenson, D. M., and P. J. Weimer. 2007. Dominance of Prevotella and low abundance of classical ruminal bacterial species in the bovine rumen revealed by relative quantification real-time PCR. Appl. Microbiol. Biotechnol. 75:165-174.

Weimer, P. J., Y. Shi, and C. L. Odt. 1991. A segmented gas/liquid delivery system for continuous culture of microorganisms on solid substrates, and its use for growth of Ruminococcus flavefaciens on cellulose. Appl. Microbiol. Biotechnol. 36:178-183.

Weimer, P. J., D. M. Stevenson, H. C. Mantovani, and S. L. C. Man. 2010a. Host specificity of the ruminal bacterial community of the dairy cow following near-total exchange of ruminal contents. J. Dairy Sci. 93:5902-5912.
Weimer, P. J., D. M. Stevenson, and D. R. Mertens. 2010b. Shifts in bacterial community composition in the rumen of lactating dairy cows under milk fat-depressing conditions. J. Dairy Sci. 93:265278.

Weinberg, Z. G., Y. Chen, and M. Gamburg. 2004. The passage of lactic acid bacteria from silage into rumen fluid, in vitro studies. J. Dairy Sci. 87:3386-3397.

Weinberg, Z. G., and R. E. Muck. 1996. New trends and opportunities in the development and use of inoculants for silage. FEMS Microbiol. Rev. 19:53-68.

Weinberg, Z. G., R. E. Muck, and P. J. Weimer. 2003. The survival of silage inoculant lactic acid bacteria in rumen fluid. J. Appl. Microbiol. 94:1066-1071.

Welkie, D. G., D. M. Stevenson, and P. J. Weimer. 2010. ARISA analysis of ruminal bacterial community dynamics in lactating dairy cows during the feeding cycle. Anaerobe 16:94-100.

Yu, Y., C. Lee, J. Kim, and S. Hwang. 2005. Group-specific primer and probe sets to detect methanogenic communities using quantitative real-time polymerase chain reaction. Biotechnol. Bioeng. 89:670-679. 